\title{
Feminist Institutionalist Interpretation of Forest Tenure Regimes in Nepal
}

\author{
Radha Wagle ${ }^{1}$, Deepa Oli ${ }^{2}$, Basana Sapkota ${ }^{3}$, Saraswati Aryal ${ }^{4}$ and Sabina Maiya Prajapati ${ }^{5}$ \\ ${ }^{1} \mathrm{PhD}$ Student, Monash University, Melbourne, Victoria, ${ }^{2}$ Department of Forests, ${ }^{3}$ ActionAid, Nepal, \\ ${ }^{4}$ Department of Forests, ${ }^{5}$ Department of Soil Conservation and Watershed Management
}

Corresponding author: radhawagle2000@yahoo.com

\begin{abstract}
Forest tenure reform is one of the key agenda for sustainable forest governance. But forest tenure is not gender neutral. We examine various forest tenure regimes of Nepal from feminist institutionalist approach and explore, to what extent, each regime recognises the right of women to forest tenure. Five community-based forest tenure regimes, namely community forest, propoor leasehold forest, collaborative forest, buffer zone community forest and conservation area are taken into account for assessing gender dimension. Historical changes and continuity are presented in forestry governance in terms of women's bundle of rights over forest resources across three key phases - before 1950s, from 1950s to 1970s and from 1970s onward. Formal and informal institutions in each of the five tenure regimes were analysed and we found that the formal institutions in community forestry recognises the roles of the women in forest tenure, but those in other regimes and informal rules in all the regimes, by and large, prevent women from having access to and control over forest resource decisions. Emerging aspects of forestry, mainly forest-based enterprises and REDD + have not been able to address gender issues properly. Some recommendations are made for gender equality in forest tenure regimes.
\end{abstract}

Key words: Feminist institutionalism, forest tenure, formal institution, informal institution, tenure regime

\section{INTRODUCTION}

Forests are vital resources for local livelihoods and national economy in developing countries (Persha et al. 2011). Forests and land together make up the backbone of agrarian production system in the global south. Forest tenure reform is one of the key agenda for sustainable forest governance across the globe (RRI 2009; FAO 2011). Clear tenure regime is regarded as an incentive for forest managers to invest in forest management with an assurance for them to reap returns from the investment (Larson et al. 2010). The reform in land and forest tenure is deployed through adoption of policies to implement various management regimes (FAO 2011). The tenure arrangement across various forest management regimes is different which reconfigures the authority and power in terms of management, use of resources and sharing of benefit accumulated from it (Agrawal and Ostrom 2001). Basically, tenure reform recognises and acknowledges the roles of different section of people, particularly the marginalised ones, such as women, indigenous peoples and local communities for their dependence on forests and their need to manage it for reaping benefits for livelihoods (Larson et al. 2010; FAO 2011). In this connection, forest tenure regimes are rapidly changing with the policy aim to better protect the resources and optimize the benefit to local people including women and other marginalised communities (Agrawal et al. 2008).

Having mentioned the forest tenure for women and marginalised groups, forestry has traditionally been criticised as a masculine profession or practice (Countinho-Sledge 2015). But this gross criticism or categorization is problematic for two reasons. First, this masculine 
connotation overlooks the roles women have been playing for caring and using forests for their livelihoods over time. Second, it implies that the devolution of power to community or household level is sufficient in forestry sector reform including tenure reform without considering gender, given its masculine nature. Even so, women have been engaged in forestry activities for centuries, particularly in the global south. Collection of fuelwood, fodder, medicinal plants and other non-timber forest products has prime responsibility of women (Shiva 1989; Agarwal 2010). Men have been mainly involved in harvesting and selling timber (Countinho-Sledge 2015). This differentiation in the roles of men and women in forestry activities allude to the gendered notion of who have control over and access to forests for what products and in what ways. All these aspects of forestry including the ways forests are controlled, accessed and used are the components of forest tenure (FAO 2011) and when these aspects are undertaken by men and women in different manner, forest tenure becomes gendered.

The gender differentiation in forest resource management and use is a contested issue in forestry sector. Pro-gender scholarships argue that women have been basically marginalised from the control over and access to forest benefits, while their engagement in sustaining forests is immense. Gender neutral scholarship emphasises on devolving authorities to lower level institutions not necessarily considering women's participation. Although women are engaged in forestry activities for ages, gender related issues in natural resource have been documented only since the initiation of Women in Development (WID) concept through
Gender and Development (GAD) in 1980s, which later turned to Gender, Environment and Development (GED) efforts (Sarker and Das 2002; BuckinghamHatfield 2005). Women's engagement in forests was a compulsion, rather than a voluntary participation, given their household responsibilities. In rural economy, women's roles such as cooking, caring, keeping livestock and other agricultural related tasks, all have direct connection with forests and their resources. In agro-economy, there are specific type of forest users and frequent users of forest products. In such society, women are the de facto managers of forest resources (Mwangi et al. 2011).

One of the 10 Principles of tenure reform identified by FAO is Social Equity (Principle 3), which emphasises the empowerment of marginalised groups, particularly women and the poor (FAO 2011). However, whether forest tenure reform embraces gender or empowers women at empirical level is often unexplored. While forestry overall is gendered (Countinho-Sledge 2015), how is forest tenure viewed from gender perspective? To answer the question, this paper examines various forest tenure regimes of Nepal from feminist institutionalist approach and explores, to what extent, each regime recognises the right of women to forest tenure.

The paper is divided into six sections. In the second section, the conceptual framework or feminist institutionalism is discussed. In the third section, historical analysis of forest tenure regimes is presented from the perspective of feminist institutional continuity and change. Formal and informal i nstitutions associated with six community-based forest tenure regimes are elaborated in the fourth section. In the 
next section, critical lights are shed from feminist perspective on two emerging forestry aspects-forest-based enterprise and Reducing Emissions from Deforestation and Forest Degradation (REDD+). Finally, conclusion is presented in the sixth section.

\section{FOREST TENURE THROUGH FEMINIST INSTITUTIONALIST LENS}

Tenure regimes are institutional landscapes or institutions that determine the rules of the game about 'access to and use of resources' (FAO 2011:5) or 'the rules and authority that regulate land use' (Robbins 1998). Forest tenure is therefore a special type of institution or the rule of the game that governs who has control over, access to and use of forest resources to what degree and for how long. Even so, forest institutions are not gender neutral, or in other words, 'all institutions are gendered' (Kenny 2014). Countinho-Sledge (2015) argues that forest institutions are either masculinized or feminized depending on the engagement of women as well as the presence of normatively feminine values in those institutions. The scholarship on institutions and gender together gives insight into forest tenure as a special institution that needs to be viewed from gender perspective. This concept of 'gendering' of forest tenure or institution is also in line with FAO Principle 3 of forest tenure reform (FAO 2011). However, literature on forest tenure reform does not guide to how forest tenure is examined through the lens of gender. Building on the concept of tenure as institution from gender perspective, we draw forest tenure regimes on 'feminist institutionalism' (Mackay et al. 2010; Kenny 2014; Krook and Mackay 2015) in order to examine six community-based forest tenure regimes of Nepal-community forest, collaborative forest, leasehold forest, protection forest, conservation area and buffer zone community forest.

Mackay et al. (2010) note that feminist institutionalism builds on the integration of feminist political science with new institutionalism, which together focus on four key facets----formal and informal institutions; institutional continuity and change; structure and agency; and gender and institutional power. Out of these four facets, following Kenny (2014), we take institutional continuity and change as well as formal and informal institutions into consideration in order to analyse forest tenure regimes from feminist institutionalist perspective. The 'institutional continuity and change' elaborate on to what extent the balance of masculine and feminine values persists and varies over time in institutions, such as forestry sector organizations. Formal and informal institutions, on the other hand, refer to the rules-in- law and rules-in-practice respectively in forestry institutions that support or obstruct the engagement and recognition of women in forestry governance.

In this paper, we assess community-based forest tenure regimes within 'institutional continuity and change' as well as 'formal and informal institutions' frameworks. The former works on a historical analysis of forestry institutions from gender perspective, while the later examines how rules of the game in community-based tenure regimes operate in favour of or against women's participation in forestry institutions. 


\section{CONTINUITY AND CHANGE IN FOREST TENURE SYSTEMS}

Frequent changes have been observed in forest tenurial arrangements after 1950s from state control to people centered forest management approach in Nepal. The internal power struggle between the State and the people coupled with the influence of international donor communities were instrumental for policy reform and reconfiguring the tenure regimes. However, the women centered policy changes have been introduced only recently. The following section describes the major changes and continuity in tenurial regimes over three major historical time frame viz. feudal ownership, state ownership and state-people mixed ownership model.

\section{Table 1: Historical Evolution of Forest Tenure Regimes in Nepal}

\begin{tabular}{|c|c|c|c|}
\hline Historical Time & $\begin{array}{l}\text { Objectives of } \\
\text { Forestry }\end{array}$ & Key Actors & $\begin{array}{l}\text { Characteristics of } \\
\text { Tenure }\end{array}$ \\
\hline \multirow{4}{*}{$\begin{array}{l}\text { Forest tenure in } \\
\text { Feudal regime } \\
\text { (Before 1951) }\end{array}$} & $\begin{array}{l}\text { Revenue, timber } \\
\text { export }\end{array}$ & \multirow{4}{*}{$\begin{array}{l}\text { Local elites/families, } \\
\text { group of families, local } \\
\text { functionaries, landlords, } \\
\text { Rana autocrats }\end{array}$} & \multirow{2}{*}{$\begin{array}{l}\text { Men's authority } \\
\text { and control over } \\
\text { women's right to } \\
\text { property }\end{array}$} \\
\hline & \multirow{2}{*}{$\begin{array}{l}\text { Protection at border, } \\
\text { homage to local } \\
\text { elites, meeting basic } \\
\text { needs of forest } \\
\text { products }\end{array}$} & & \\
\hline & & & $\begin{array}{l}\text { Management rights } \\
\text { were formally } \\
\text { handed over to men }\end{array}$ \\
\hline & $\begin{array}{l}\text { Conversion of forest } \\
\text { land for resettlement }\end{array}$ & & $\begin{array}{l}\text { Women had access } \\
\text { to forest product } \\
\text { such as fuelwood, } \\
\text { fodder, medicinal } \\
\text { plants to meet their } \\
\text { basic needs }\end{array}$ \\
\hline \multirow{6}{*}{$\begin{array}{l}\text { Nationalization } \\
\text { (1950s- 1970s) }\end{array}$} & Protection, & State, state authority & \multirow{6}{*}{$\begin{array}{l}\text { State control over } \\
\text { management and } \\
\text { utilisation of forest } \\
\text { resulted in rapid } \\
\text { deforestation and } \\
\text { depletion of forest } \\
\text { resources } \\
\text { Access to forest } \\
\text { resources for women } \\
\text { such as fuelwood, } \\
\text { fodder, litter and } \\
\text { medicinal herbs was } \\
\text { not significantly } \\
\text { changed though the } \\
\text { resource was scarce }\end{array}$} \\
\hline & $\begin{array}{l}\text { conservation and } \\
\text { utilization of forest }\end{array}$ & $\begin{array}{l}\text { such as Department of } \\
\text { Forest, forest officials }\end{array}$ & \\
\hline & $\begin{array}{l}\text { considering it as } \\
\text { national wealth }\end{array}$ & \multirow[t]{4}{*}{$\begin{array}{l}\text { donors, local political } \\
\text { bodies }\end{array}$} & \\
\hline & \multirow{2}{*}{$\begin{array}{l}\text { Ensure state } \\
\text { control over forest } \\
\text { throughout the } \\
\text { national territory }\end{array}$} & & \\
\hline & & & \\
\hline & $\begin{array}{l}\text { Not well-defined } \\
\text { management } \\
\text { objectives }\end{array}$ & & \\
\hline
\end{tabular}




\begin{tabular}{llll}
\hline $\begin{array}{l}\text { Community } \\
\text { based forest } \\
\text { management }\end{array}$ & $\begin{array}{l}\text { People's } \\
\text { participation in } \\
\text { forest management }\end{array}$ & $\begin{array}{l}\text { State, Department } \\
\text { of Forest and } \\
\text { its subsidiary } \\
\text { (1980s onwards) }\end{array}$ & $\begin{array}{l}\text { Legitimate } \\
\text { management rights } \\
\text { to local community }\end{array}$ \\
& $\begin{array}{l}\text { Contribute to uplift } \\
\text { the livelihoods of } \\
\text { local people through } \\
\text { different economic } \\
\text { activities }\end{array}$ & $\begin{array}{l}\text { local communities, } \\
\text { Development partners, } \\
\text { local governments, } \\
\text { networks, alliances, } \\
\text { civil society, } \\
\text { entrepreneurs, private } \\
\text { sector }\end{array}$ & $\begin{array}{l}\text { Increased women's } \\
\text { access to forest } \\
\text { resources and } \\
\text { participation in } \\
\text { decision making } \\
\text { process, women }\end{array}$ \\
& & & $\begin{array}{l}\text { leadership became } \\
\text { mandatory. Benefit } \\
\text { sharing mechanism } \\
\text { in favour of }\end{array}$ \\
& & & $\begin{array}{l}\text { women and other } \\
\text { disadvantaged group }\end{array}$ \\
\hline
\end{tabular}

Source: Gilmour and Fisher (1991); Hobley and Malla (1996); Bhattarai et al. (2002)

\section{Feudal Forest Tenure Regimes (before 1950s)}

During feudal Rana rules, forests were major sources of revenue generation and power. Rana rulers largely controlled forests in the country. Ranas would allocate forest lands to elite families, who in turn, would use local tenants for forest protection and harvesting. Forests, as well as other land resources were allocated as Jagir ${ }^{1}$, Kipat ${ }^{2}$, Birta ${ }^{3}$, Guthi $i^{4}$ to vassals and other families belonging to Rana rulers based on some legal documents (lalmohar, sanad). The ownership of land along with the right of withdrawal was with the state, whereas tenants were responsible for collecting revenues and protecting forests for which they would pay certain revenue to the State through the functionaries on a regular basis. Local people had access to some minor forest products (fuelwoods, grasses, leaflitters)

1. Jagir is an assignment of income from state owned lands to government officials, military men, etc. in exchange for their services. 2. Kipat is a traditional form of communal land tenure.3. Birta is an assignment of income from state owned (Raikar) lands to an individual such as a priest, soldier, and member of the nobility or royal family.4.Gutbi is a permanent form of Birta given to institutions such as temples, monasteries, schools, hospitals, etc. free of costs while they had to pay cash or in-kind to obtain timber. The forest lands which were suitable for agriculture could be converted to farm land in functionaries' discretion (Acharya et al. 2008). Women were engaged as agriculture labour as well as forest dwellers. Since, the society was largely patriarchal, male member had the authority over land including forests. Based on traditional roles of Nepalese women, it can be argued that they could have access to some forest products and agricultural products to meet their basic needs as they have the responsibility to secure food for their family. During the feudal Rana regime, despite having access to the forest resources, women had no control over the forest land and its resources. Domination of patriarchy persisted in forest management, while the land tenure gradually changed from feudal ownership to State ownership (Regmi 1976).

\section{State Forest Tenure Regimes (1950-1980)}

Following the fall of Rana oligarchy in 1950, the new government nationalised all the forests in 1957 pursuant to Forest 
Nationalization Act of 1957. The Act defined all the trees planted in private land as forests and brought under government ownership. This act succeeded to shift the authority of forest land from people to state but failed to convince the people for forest management due to the lack of clear management objectives. The law created fear among general people about insecurity of land right which contained trees. That led to mass scale deforestation across the country so the land could be protected from being nationalised. Industrialisation and resettlement program also invited deforestation in the Terai. The loss of forest resources had impact on women due to the scarcity of forest products, mainly fuelwood, fodder, grasses and medicinal plants. Such scarcity of resources created hardship for women by increasing their travel time and work burden to collect forest resources.

Deforestation in the Nepalese hills with its downstream effects was a major concern in the international arena during 1970s, which was also known as the 'Theory of Himalayan Environmental Degradation' by some Malthusian scholars (Ives and Messerli 1989). Pursuant to this concern, international organizations such as the World Bank expressed their interests to support Nepalese forestry sector during 1970s. Emphasis laid on community participation in forest management in Nepal. The ninth National Forestry Conference held in Kathmandu in 1970 also recognised the importance of community participation forest management (Gilmour and Fisher 1991). Consequently, in 1976 the National Forestry Plan was formulated by acknowledging the role of community participation for forest management but it did not explicitly recognise the role of women in forestry, nor it mentioned about gender issues. Persistence of patriarchy in the form of male only structure of the Department of Forest existed, while tenure regimes shifted from pure statecontrolled towards the involvement of local people in the protection and use of forest resources (Bhattarai et al. 2002).

\section{Community Based Forest Tenure Regimes (1980s onwards)}

In 1980s, decentralisation of forest management was introduced through Panchayat and Panchayat protected forests with the role of village political unit (Rural Panchayat) in such tenure regimes (Bhattarai et al. 2002). The peculiarity of this regime was that the patches of degraded forest were handed over to the Panchayat for protection, management and utilisation. It was the first attempt of government to transfer the forest management right to the local community, though women were not considered as stakeholders of forest management (Giri 2012). Such institutions were often headed by male individuals where no representation of women was formally ensured, hence, any decisions regarding the forest management and use of forest resources were made by male elites. The strict protection regime of forest through panchayat suspended women's traditional use right of forest products where the regime was in practice, let alone the establishment of women's right over forest resources.

Panchayat forestry was a failure in terms of protecting forests, mobilising people's participation and ensuring effective delivery of local benefits from forest resources (GON 1988). Panchayat units were too big to focus on patches of forests for their effective management, while the units had other priorities, such as infrastructure development. This governance 
gap was fulfilled by introducing 'user group' concept in the Master Plan for Forestry Sector in Nepal followed by inclusion of this concept in Forest Act 1993 and Forest Regulation 1995.

The introduction of community forestry in terms of user group concept shifted the authority of forest management from the State or the Rural Panchayat to lower level institutions. But the dominance of males in forestry decisions in both the Department of Forest and user groups continued. Community forestry was a harbinger to a number of 'communitybased forest tenure regimes including leasehold forest, collaborative forest, buffer zone community forest and conservation area. These community based regimes have varied configurations of tenure arrangement affecting gender dimension in these regimes. In the following section, these regimes are examined from the perspective of formal and informal institutions affecting women engaged in forestry.

\section{FORMAL AND INFORMAL INSTITUTIONS}

A number of community-based forest tenure regimes have been initiated with varied degree of bundle of rights particularly since the year 2000. Out of them, we studied community forest, pro-poor leasehold forest, collaborative forest, buffer zone community forest and conservation area in this paper (Table 2). Formal and informal institutions of these tenure regimes from feminist viewpoint were examined. The formal rule of the game in community forest is institutionally robust in favour of women. Their access to forest resources, space for their leadership development an equitable benefit sharing is instituted in the case of community forestry. However, the social norms and values, which are the informal institutions, often prevent women from realising the full rights and benefits the formal institutions offer to them.

Table 2: Formal and Informal Institutions in CBFM from Feminist Viewpoint

\begin{tabular}{|c|c|c|c|}
\hline \multirow{2}{*}{$\begin{array}{l}\text { Tenure } \\
\text { regimes }\end{array}$} & \multirow[t]{2}{*}{ variables } & \multicolumn{2}{|l|}{ Rights and access } \\
\hline & & Legal (formal institutions) & $\begin{array}{l}\text { Customary practises } \\
\text { (Informal institutions) }\end{array}$ \\
\hline \multirow{3}{*}{ 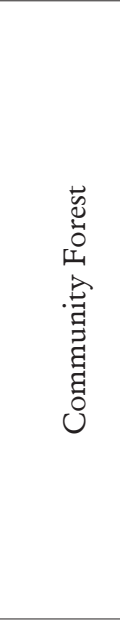 } & $\begin{array}{l}\text { Forests products } \\
\text { use and access }\end{array}$ & $\begin{array}{l}\text { - Considered women as a primary } \\
\text { user }\end{array}$ & $\begin{array}{l}\text { Primary user } \\
\text { Traditional access to } \\
\text { forest product } \\
\text { Insufficient supply of } \\
\text { forest product because } \\
\text { of small and degraded } \\
\text { areas for women only } \\
\text { CF }\end{array}$ \\
\hline & $\begin{array}{l}\text { Participation } \\
\text { in institutional } \\
\text { processes }\end{array}$ & $\begin{array}{l}\text { - Both male and female as an official } \\
\text { member of CFUG } \\
\text { At least } 50 \% \text { female participation } \\
\text { with representation in either } \\
\text { chairperson or secretary or both }\end{array}$ & $\begin{array}{l}\text { - Social norms and } \\
\text { practices act as } \\
\text { hindrance for } \\
\text { meaningful participation } \\
\text { of women }\end{array}$ \\
\hline & Benefit sharing & $\begin{array}{l}\text { - CFUG reaps } 100 \% \text { benefits out of } \\
\text { the CF. } \\
\text { - } 35 \% \text { of CF's income for poor, } \\
\text { marginalised and women }\end{array}$ & $\begin{array}{l}\text { Only about } 15 \% \text { of } \mathrm{CF} \\
\text { Income spent for poor } \\
\text { and marginalised on } \\
\text { average }\end{array}$ \\
\hline
\end{tabular}




\begin{tabular}{|c|c|c|c|}
\hline 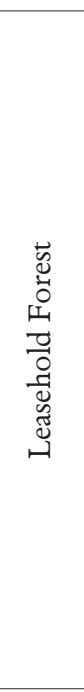 & $\begin{array}{l}\text { Participation } \\
\text { in institutional } \\
\text { process }\end{array}$ & $\begin{array}{l}\text { Primary user } \\
\text { Access to forest products planted } \\
\text { and grown by the groups } \\
\text { Restriction for harvesting older } \\
\text { trees } \\
\text { - Membership for both male and } \\
\text { female } \\
\text { No reservation in executive } \\
\text { committee } \\
\text { Compulsory participation of } \\
\text { woman and man from each } \\
\text { household in trainings } \\
\text { No legal mandatory for female in } \\
\text { benefit sharing but has access on } \\
\text { resource utilization as being the part } \\
\text { of family } \\
\text { More advanced groups organized } \\
\text { into cooperatives for financial } \\
\text { activities }\end{array}$ & $\begin{array}{l}\text { - Involvement of pro } \\
\text { poor household } \\
\text { Women are benefitted } \\
\text { but not targeted } \\
\text { - Women participation } \\
\text { ensured from the initial } \\
\text { phase to benefit sharing }\end{array}$ \\
\hline 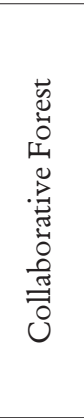 & $\begin{array}{l}\text { Use of and } \\
\text { access to forest } \\
\text { products. } \\
\text { Participation } \\
\text { in institutional } \\
\text { process } \\
\text { Benefits sharing }\end{array}$ & $\begin{array}{l}\text { - Of the total Timber and fuelwood } \\
\text { harvested Only } 50 \% \text { is for users } \\
\text { No provision of benefit sharing to } \\
\text { marginalised group } \\
\text { Participation of women in } \\
\text { mandatory }\end{array}$ & $\begin{array}{l}\text { Male dominancy due } \\
\text { to higher economic } \\
\text { benefits from timber } \\
\text { - Only } 10 \% \text { of the } \\
\text { total members in the } \\
\text { committee are women. } \\
\text { DFO decides on major } \\
\text { issues hence women's } \\
\text { voice is often unheard. } \\
\text { Only vocally led } \\
\text { women are benefitted }\end{array}$ \\
\hline 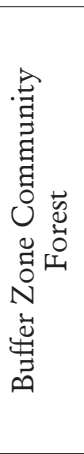 & $\begin{array}{l}\text { Use of and } \\
\text { access to forest } \\
\text { products. } \\
\text { Participation } \\
\text { in institutional } \\
\text { process } \\
\text { Benefits sharing }\end{array}$ & $\begin{array}{l}\text { Women's access to forest resources } \\
\text { is not formally recognised } \\
\text { Provision for geographical } \\
\text { representation, along with at least } \\
\text { three women members in BZFUG } \\
\text { management committee } \\
\text { BZFUG reaps } 100 \% \text { benefits } \\
\text { from BZCF, but no provision } \\
\text { for spending the benefit for } \\
\text { marginalised and women. }\end{array}$ & $\begin{array}{l}\text { Women have access to } \\
\text { buffer zone forests for } \\
\text { fuelwood and fodder } \\
\text { Women are less } \\
\text { represented than men. } \\
\text { Women's voice is often } \\
\text { unheard during decision } \\
\text { making } \\
\text { Leaders pay more } \\
\text { attention to cash income } \\
\text { like eco-tourism. } \\
\text { Women's need of forest } \\
\text { products is overlooked. }\end{array}$ \\
\hline 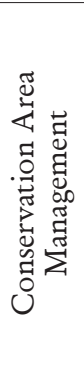 & $\begin{array}{l}\text { Participation } \\
\text { in institutional } \\
\text { process } \\
\text { Benefits sharing }\end{array}$ & $\begin{array}{l}\text { Women's access to forest resources } \\
\text { are not formally recognised } \\
\text { - } \begin{array}{l}\text { Provisions for conservation officer } \\
\text { to nominate women, disadvantaged } \\
\text { group members and social workers }\end{array} \\
\text { - Local people get financial benefit }\end{array}$ & $\begin{array}{l}\text { Women have access to } \\
\text { conservation area forests } \\
\text { for fuelwood and fodder } \\
\text { with some restriction } \\
\text { Role of women } \\
\text { depends on the mercy } \\
\text { or discretion of } \\
\text { conservation officer } \\
\text { Women are deprived } \\
\text { of direct benefit from } \\
\text { conservation area }\end{array}$ \\
\hline
\end{tabular}

Source: Nagendra (2002); Jhaveri and Adhikari (2015); DNPWC (2016) 
Pro-poor leasehold forest has instituted some formal rules in favour of women, such as equal number of men and women to be the member of the leasehold group. Same number of male and female has been made mandatory for them to participate in trainings offered by the Department of Forests. When it comes to benefit sharing from the leasehold forests, often the male members have found to be benefitted. The informal rules are not as conducive as the formal ones for women in propoor leasehold forests. Collaborative forest has got a lump-sum provision of including women in its management committee, but no quota is fixed. The management system is often timber driven in collaborative forest, and therefore, the role of men becomes dominant in decision making. Informal rules are also malefriendly. Buffer Zone Community Forest and Conservation Area Management are mainly focused on biodiversity conservation and eco-tourism. Formal rules have very minimal space for women to take a lead, while informal institutions in these tenure regimes also emphasize cash benefits often at the expense of the needs of women. Overall, wherever women are encouraged to participate in forest tenure regimes, it is limited in attending meetings, which are not enough for women to influence decision making. The silent participation of women in such affair further encouraged males to make decision in favour of themselves and legitimatise their agenda.

\section{WOMEN IN FOREST-BASED ENTERPRISES}

Forest-based enterprise is an emerging avenue, which could address women's social and economic needs. Women have been engaged in collecting Non-Timber
Forest Products (NTFPs) from forests for many years. But their involvement in NTFP collection is often not recorded and are usually underpaid for their job. Studies note that women are massively engaged in collecting and selling, processing and preparing of NTFP based forest products (Basik 2012). It is the traditional role of women rather than the policy backing that women have been engaged in NTFP business (Biggs and Messerschmidt 2005).

A study carried out in Parbat, Myagdi and Baglung district found 58 per cent women participation in various enterprises supported by Multi-stakeholder Forestry Programme (MSFP) even though most of them are agriculture-based enterprises (agriculture and livestock) (Pandey 2016). The success of agriculture based enterprises was correlated to easy access to forest products to sustain the enterprise. In forest based enterprises, involvement of women is higher in Lokta paper making, preparation of Bel juice, Allo fiber making and weaving, collection of raw materials for such enterprises. However their role is negligible in timber industry (Biggs and Messerschmidt 2005). Apart from NTFPs, women have started to involve in nursery related forest enterprises following their participation in skill development training from development organizations (RRN 2012).

Although women are partially involved in NTFP enterprises, they are almost absent in timber enterprises. The only female timber contractor in one of the Terai districts mentioned that women have difficulties in getting involved in such industry due to socio cultural reason and lack of government's empowerment policy (personal communication with Laxmi Shahi). She further added that dealing with government staff is difficult task due to 
lack of female staff in the forestry offices. Various capacity building programmes are provided by different organisations to increase poor and women's access in forestry enterprises. However, such programmes are limited to collecting and processing rather than enhancing entrepreneur skills. Women still lack access to market, value chain addition and fund for investment in forestry enterprises, let alone wage discrimination between men and women (Basik 2012).

\section{WOMEN IN REDD+}

Reducing Emission from Deforestation and Forest Degradation and associated forestry activities (shortly known as REDD+) is lauded for enhancing benefits to local communities including women. Social safeguard mechanism is devised in order to mitigate adverse impacts of REDD + on the social system. It entails that the rights of women over forest resource are not curtailed at all, rather they are augmented. However, REDD + policies, processes and piloting are argued as gender insensitive in many respects (WOCAN 2012; Giri 2012). The available policy documents on REDD + such as Readiness Preparation Proposal(R-PP), REDD + Interim Strategy and REDD + piloting projects have given less importance to gender related issues. The participation of and consultation with women in REDD + policy, processes and institutions was minimal and not ensured. The implication of such insensitiveness in gender issues impacted women's tenure regimes during the implementation of REDD + piloting programmes. Giri (2012) mentioned that the restriction imposed by community forest user groups, during the piloting of REDD+ program had significantly impacted on women's access to forest resources. Women were found to be deprived from using forest resources and their existing tenure rights to access and use was suspended while REDD+ piloting was carried out.

In the readiness phase of REDD+, Nepal has produced documents such as Forest Reference Level (FRL), Emission Reduction Program Document (ERPD) and its associated documents for 12 Terai districts. However, during the preparation of ERPD, emphasis has been given to Indigenous People (IPs) and Local Communities (LCs) but the gender component is not explicitly spelled out. Moreover, the REDD+ safe guard measures also overlooked the gender component while only IPs and LCs are focused. Large body of literature in gender issues on forest resource management in Nepal has highlighted the material based (fuelwood, fodder, leaf litters) needs of women to lessen their hardship deeply rooted in Nepalese social, cultural and institutional practices (Khadka et al. 2014). Failing to acknowledge such issues which have strong association with tenure security of women while implementing REDD+ may lead to masculinisation of REDD+ programme by further marginalising women from existing tenure security and excluding them from potential benefits. Implementation of REDD + should not only insure the current tenure rights of women but also needs to ensure the rights of women over the potential benefits from it in the long run.

\section{CONCLUSIONS AND WAY FORWARD}

We argued that forest tenure regimes are neither grossly masculine nor gender neutral, but they are highly gendered. Forest tenure reform towards devolving authority to community levels has not been sufficient to recognise women's roles in control over, access to and use of forest 
resources. Rather, forest tenure regimes have continued the gender inequality when it comes to the devolution of power from state to community level. Feminist institutionalist analysis of Nepal's community-based forest tenure regimes suggests that forest tenure affects and is affected by formal and informal rules of the game which by large contributes to the continuation of existing power relation between males and females. Nonetheless, community-based forest tenure regimes are not monolithic or uniform from gender perspective. Some tenure regimes have more conducive formal institutions or rules of the game for women inclusion than others, while the informal institutions or rules of the game in all tenure regimes resist change toward gender equality. The very recent trend in forestry, such as emergence of forest-based enterprises and REDD+ has also not been able to sufficiently address the gender issues associated in forestry sector. The following three ways forward are recommended from feminist institutionalist perspective in order to respond to the problems associated in forest tenure regimes:

First, reconciliation between formal and informal institutions or rules in community-based forest tenure regimes. While community forest tenure regime has formal rules towards gender equality, the informal values and practices are still masculine in this regime. More emphasis is to be laid on meaningful inclusion of women in the given positions and provide space for them to deliver their voices and power.

Second, break the informal institutions that is masculine by nature. It applies to all forest tenure regimes. Women's participation in all six forest tenure regimes is symbolic, rather than actual. Even in community forests, while the formal institutions or rules are in favour of gender equality in participation and power, social norms and values prevent them from realising these opportunities to the fullest extent.

Third, devolve bundle of rights to the community level. Having said that community-based forest tenure regimes still have problems in addressing gender issues. If we analyse the continuity and change pattern in the historical analysis, more space have been provided to women in CBFM than other forms of tenure regimes at least at the token scale. The more bundle of rights assigned to community level, the more formal institutions are created for women's inclusion. It can be seen from the experiences of community forest tenure regime, where equal opportunities for women's right have been instituted, which cannot be imagined in more statecontrolled regimes.

\section{REFERENCES}

Acharya, K.P., Adhikari, J. and Khanal, D.R. 2008. Forest Tenure Regimes and Their Impact on Livelihoods in Nepal. Journal of Forest and Livelihood, 7(1): 6-18.

Agarwal, B. 2010. Does Women's Proportional Strength Affect their Participation? Governing Local Forests in South Asia. World Development, 38(1), 98-112.

Agrawal, A., Chhatre, A., and Hardin, R. 2008. Changing Governance of the World's Forests. Science, 320(5882), 1460-1462.

Agrawal, A. and Ostrom, E. 2001. Collective Action, Property Rights, and Decentralization in Resource Use in India and Nepal. Politics and Society, 29(4), 485-514.

Basik, N. 2012. The Role of Women in Asia's Community Forest Enterprises. Washington, DC: Rights and Resources Initiatve

Bhattarai, K., Conway, D. and Shrestha, N. R. 2002. The Vacillating Evolution of Forestry Policy in Nepal: Historically Manipulated, Internally Mismanaged. International Development Planning Review, 24(3), 315-338.

Biggs, S. and Messerschmidt, D. 2005. Social Responsibility in the Growing Handmade 
Paper Industry of Nepal. World Development: 33(11): 1821-1844.

Buckingham-Hatfield, S. 2005. Gender and Environment. London: Routledge.

Countinho-Sledge, P. 2015. Feminized Forestry: The Promises and Pitfalls of Change in a Masculine Organization. Gender, Work and Organization, 22(4), 375-389.

DNPWC. 2016. Policy and Legal Provisions for Protected Area Management and Wildlife Conservation in Nepal (in Nepali). Department of National Park and Wildlife Conservation, Government of Nepal, Kathmandu, Nepal.

FAO. 2011. Reforming forest tenure: Issues, Principles and Process. Rome: Food and Agriculture Organization of the United Nations.

Gilmour, D. A. and Fisher, R. J. 1991. Villagers, Forests, and Foresters : the Philosophy, Process, and Practice of Community Forestry in Nepal. Kathmandu: Sahayogi Press.

Giri, K. 2012. Gender in Forest Tenure. Prerequisite for Sustainable Forest Management in Nepal. Washington, DC: Rights and Resources Initiatve.

GON. 1988. Master Plan for the Forestry Sector, Nepal: Main Report. Kathmandu: Government of Nepal, Ministry of Forests and Soil Conservation, Kathmandu, Nepal.

Hobley, M. and Malla, Y. 1996. From Forests to Forestry- the Three Ages of Forestry in Nepal: Privatization, Nationalization, and Populism. In: M. Hobley (Ed.), Participatory Forestry: The Process of Change in India and Nepal (pp. 65-92). London: Rural Development Forestry Network, Overseas Development Institute.

Ives, J. D. and Messerli, B. 1989. The Himalayan dilemma : reconciling development and conservation. Tokyo, London, New York: The United Nations University ; Routledge.

Jhaveri, N. J. and Adhikari, J. 2015. Nepal Land and Natural Resource Tenure Assessment for Proposed Emission Reductions Program in the Terai Arc Landscape. Washington, DC: USAID Tenure and Global Climate Change Program.

Khadka, M., Karki, S., Karky, B. S., Kotru, R. and Darjee, K. B. 2014. Gender equality challenges to the REDD + initiative in Nepal. Mountain Research and Development, 34(3), 197-207.

Kenny, M. 2014. A Feminist Institutionalist Approach. Politics and Gender, 10(4), 679-684.

Krook, M. L. and Mackay, F. 2015. Introduction: Gender, Politics and Institutions. In M. L. Krook and F. Mackay (Eds.), Gender, Politics and Institutions: Towards a Feminist
Institutionalism. New York: Palgrave Mac Millan.

Larson, A. M., Barry, D. and Dahal, G. R. 2010. Tenure Change in Global South. In A. M. Larson, D. Barry, G. R. Daha \& C. J. P. Colfer (Eds.), Forests for People: Community Rights and Forest Tenure Reform (pp. 3-18). London, Earthscan

Mackay, F., Kenny, M. and Chappel, L. 2010. New Institutionalism Through a Gender Lens: Towards a Feminist Institutionalism? International Political Science Review, 31(5), 573-588.

Mwangi, E., Meinzen-Dick, R. and Sun, Y. 2011. Gender and sustainable forest management in East Africa and Latin America. Ecology and society, 16(1).

Nagendra, H. 2002. Tenure and Forest Conditions: Community Forestry in the Nepal Terai. Environmental Conservation, 29(04), 530-539.

Pandey, R.R. 2016. Pro-Poor Livelihoods: An Experience from the Multi Stakeholder Forestry Programme (MSFP): Working Paper. Local Initiatives for Biodiversity, Research and Development (LI-BIRD), Kaski.

Persha, L., Agrawal, A. and Chhatre, A. 2011. Social and Ecological Synergy: Local Rulemaking, Forest Livelihoods, and Biodiversity Conservation. Science, 331(6024), 1606-1608.

Regmi, M.C. 1976. Landownership in Nepal. Berkeley, Los Angeles, University of California Press.

Robbins, P. 1998. Authority and Environment: Institutional Landscapes in Rajasthan, India. Annals of the Association of American Geographers, 88(3), 410-435.

RRI. 2009. Who Owns the Forests of Asia? An Introduction to the Forest Tenure Transition in Asia 2002-2008. Washington, DC: Rights and Resources Initiatve.

RRN. 2012. Social and community Forestry in Practice RRN's 20 Years of Experiences in Community Based Natural Resource Management. Rural Reconstruction Nepal, Kathmandu, Nepal.

Sarker, D. and Das, N. 2002. Women's Participation in Forestry. Economic and Political Weekly, 37(43).

Shiva, V. 1989. Staying Alive: Women, Ecology and Development. London: Zed Books.

WOCAN. 2012. An Assessment of Gender and Women's Exclusion in REDD+ in Nepal: Case Study. Women Organizing for Change in Agriculture \& Natural Resource Management (WOCAN), Kathmandu, Nepal. 